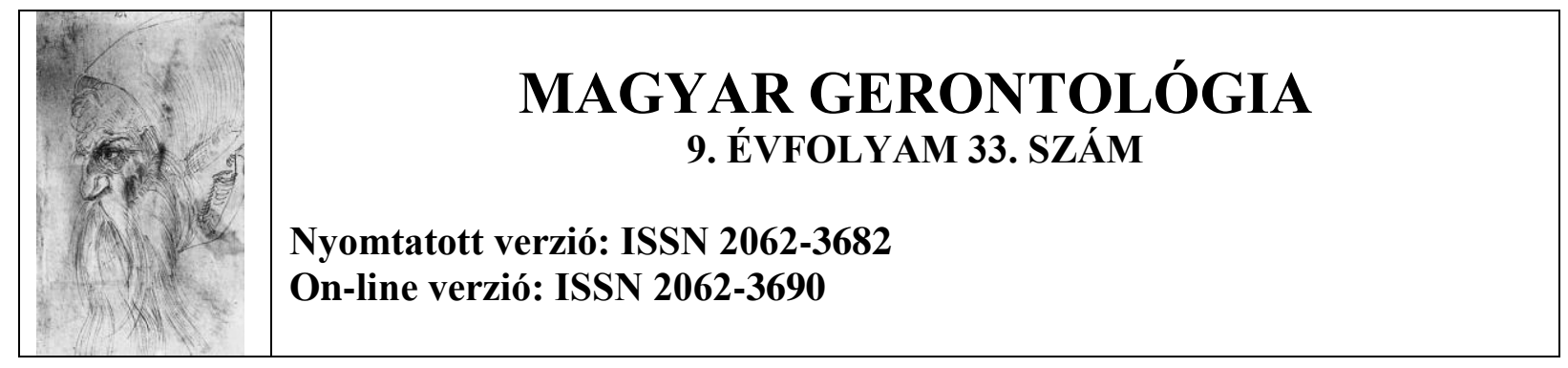

\title{
Idősek nappali ellátása a Nyíregyházi Szociális Gondozási Központban ${ }^{1}$
}

\section{Barna Hilda}

Kulcsszavak: idősek nappali ellátása, minőségi idősödés

\section{Összefoglalás}

Előadásomban bemutatom a Nyíregyházi Gondozósai Központ idősek nappali ellátásának intézményi hátterét. Bemutatom a legfontosabb alapelveket és célokat, melyeket a programok szervezése során szem előtt tartunk. Ismertetem a legfontosabb programokat, melyek mindegyike hozzájárul az idősek testi-lelki és szociális egészségének megőrzéséhez, az élethosszig tartó tanulás megvalósulásához, és a minél tovább tartó önálló életvitelhez.

\section{Bevezetés}

Magyarország, hasonlóan a többi európai országhoz az öregedő társadalmak közé sorolható. Ennek hátterében az időskorúak számának és számarányának emelkedése áll, ami egyrészt a születések számának csökkenésével, másrészt a várható élettartam növekedésével indokolható.

Magyarország népességéből a 65 éves és idősebbek száma 2014. január 1-én közel 1 millió 732 ezer volt, amely a népesség 17,5\%-a. A társadalom tagjai számára nagy kihívást jelent az időskorúak számarányának emelkedése (1. ábra).

Napjainkban nem jellemző, hogy az idősek gyermekeikkel és unokáikkal, többgenerációs családban élnek együtt. Az életkor elörehaladtával - döntően az özvegyülés következtében - folyamatosan nő az egyedül, özvegyen egyszemélyes háztartásban élők

\footnotetext{
${ }^{1}$ Az előadás a Nyíregyházi Gerontológiai Napok 2016. évi Konferenciáján hangzott el
} 
aránya. A többgenerációs családok felbomlása, a nők munkavállalása és ebből adódóan a családi gondozási lehetőségek beszükülése is hozzájárult az időskorúak esetében ahhoz, hogy inkább az intézményes ellátásokat veszik igénybe. Különösen súlyos az egyedül élő idősek helyzete, akik fokozott közösségi gondoskodásra szorulnak. Az idősellátás a szociális ellátórendszer egyik legnagyobb ága, ahol az ellátási igények folyamatosan nőnek.

1. Számú ábra: Az ellátottak számának alakulása 1995-2013

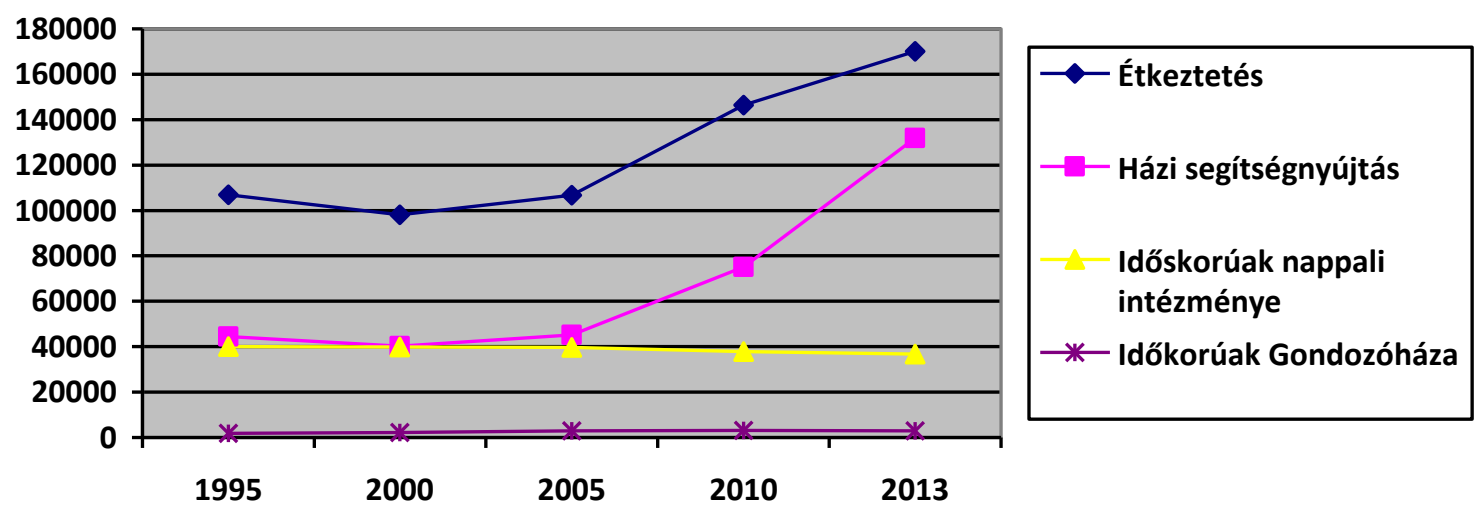

Forrás: KSH 2014.

A korszerü idősellátás törekvése az, hogy az idős embert a saját környezetében kell ellátni, addig, amíg csak lehetséges. A területi idősellátás elsődleges feladata az otthonukban élő időskorúak segítése. Ez elsősorban a házi segítségnyújtással valósul meg, valamint a különösen veszélyeztetett klienskör számára a jelzőrendszeres házi segítségnyújtással. Ezeket a szolgáltatásokat kiegészíti az étkeztetés biztosítása, valamit a támogató szolgálat keretében a szállítás biztosítása. Fontos láncszem az ellátásban az átmeneti gondozóház, amely lehetőséget nyújt arra, hogy az egészségügyi ellátásból kikerült, de még fokozott gondozást igénylő idősek átmeneti gondozását biztosítsa, illetve a családban élő, gondozásra szoruló, de az életkörülmények átmeneti változása miatt ellátást igénylő idős emberek számára biztosítson ideiglenes gondozási hátteret. A területi ellátás formái között szerepel az idősek klubja, amely közösségi teret és aktivitási lehetőséget biztosít az idősek számára.

\section{A Nyíregyházi Gondozási Központ idősek klubjainak szolgáltatásai}

A Nyíregyházi Szociális Gondozási Központ hét idősek klubját müködtet Nyíregyháza város területén, 181 engedélyezett férőhellyel. A nappali ellátás igénybevétele térítésmentes a 
fenntartó térítési díj rendelete alapján. A nyitva tartás ideje: hétfötől csütörtökig $7^{30}-16^{00}$-ig tart, pénteken $7^{30}-13^{30}$-ig, kivétel a Nyírszőlősi Idősek Klubja ahol hétfőtől péntekig 8-16 óráig tartanak nyitva és a 3. sz. Idősek Klubja, ahol az év minden napján $8^{00}-16^{00}$-ig állnak a klubtagok rendelkezésére.

A klubok a saját otthonukban élőknek biztosítanak lehetőséget a napközbeni tartózkodásra, az igény szerinti napi étkezésre, társas kapcsolatok kialakítására. A jogszabályokban rögzített személyi és tárgyi feltételek a klubok müködéséhez biztosítottak.

Az idősek klubja a következő szolgáltatásokat nyújtja az igénybe vevők számára:

$\Rightarrow$ az 1993. évi III. törvény 62. §. szerinti étkeztetés helyben fogyasztással, valamint a szükségleteknek megfelelően reggeli és uzsonna biztosítása,

$\Rightarrow$ szabadidős programok szervezése,

$\Rightarrow$ fizikai, szellemi és szórakoztató jellegü foglalkozások szervezése, a szellemi frissesség megőrzése, az önellátásra való képesség megtartása és az élettől való elszigetelődés megakadályozása érdekében,

$\Rightarrow$ rendszeres orvosi ellátás biztosítása a körzetben lévő háziorvos közremüködésével,

$\Rightarrow$ segítségnyújtás hivatalos ügyek intézésében,

$\Rightarrow$ életvitelre vonatkozó tanácsadás, életvezetés segítése,

$\Rightarrow$ egyéni esetkezelés,

$\Rightarrow$ mentális gondozás.

Az idősek klubjaiban az aktivitás szinten tartása és fejlesztése érdekében a következő szakmai irányelvek betartására törekszünk:

- Életmódbeli aktivitás megőrzése.

- Mozgásképesség fenntartását célzó tevékenységek is rendszeresek az idősek klubjaiban a napi torna és a szükség szerinti gyógytorna biztosításával.

- Mentális és szellemi aktivitás megőrzése: ez különböző csoportfoglalkozások keretein belül történik, melyek egyrészt kreatív tevékenységek, másrészt emlékezetébresztő, a memóriát és a koncentrációs képességeket erősítő csoportok, valamint a gondolkodást és a kreativitás kibontakozását támogató csoportok, továbbá műkedvelő, müvészeti csoportok.

Az ellátottak igény és állapotfelmérésére különböző tesztek állnak a szakemberek rendelkezésére. Az aktivitási készséget, funkcionális függetlenséget, fizikai önellátó 
képességet, mozgáskészséget a következő tesztek mérik: pl.: Barthel index, Katz-ADL index, IADL skála, szociális készségszint felmérés. Az idősek kognitív és mentális állapotának, illetve pszichés jellemzőinek megismerését a következő tesztek segítik: Mini Mental Teszt, Órarajzolási teszt, Geriátriai Depresszió Szűrő Skála, Beck-féle Reménytelenség Skála.

A klubokban a foglalkozások tematikájának és módszereinek megválasztását nagymértékben befolyásolják a klubtagok készségei, képességei, motivációjuk, érdeklődési körük. A munkaterv havi, heti bontása tartalmazza az ellátottak számára szervezett programokat, mely a faliújságokon kifüggesztésre kerül, illetve a foglalkozások elött a kollégák személyesen is tájékoztatják az időseket. A havi vagy heti foglalkoztatási terv lehetőséget nyújt a gondozottaknak, hogy választani tudjanak a számukra megfelelő programok közül.

\section{A szolgáltatások megszervezésének alapelvei}

Az aktivitásnál, a foglalkozások megszervezésénél következő alapelveket követik a munkatársak:

Célszerüség, hasznosság: a tevékenységnek, a foglalkozásnak legyen valamilyen célja. A semmire sem jó, értelmetlen tevékenység még a semmittevésnél is rosszabb. A tevékenység célját a foglalkozás megkezdésekor ismertetik a klubtagokkal.

Önkéntesség: az idősek önként, saját elhatározásukból vesznek részt a tevékenységekben. Fontos, hogy ne érezzék kényszerüségnek a foglalkozásokon való részvételt. Több választási lehetőséget és alkalmat kínálunk fel a számukra, hogy kedvük, érdeklődési körük szerint választani tudjanak a programok közül.

Folyamatosság, rendszeresség: A foglalkozások folyamatossága nagyon fontos. Arra törekszünk, hogy ne legyenek alkalomszerüek, bizonytalan időközönként megrendezettek. $\mathrm{Ne}$ legyenek egyhangúak, mert a résztvevők elvesztik az érdeklődésüket. A fizikai és szellemi jellegű foglakozásokat igyekszünk váltakozva beiktatni az ellátottak napirendjébe. A rendszeresen megtartott foglalkozásokat várják és igénylik a klubtagok.

Mértéktartás: Figyelembe vesszük az ellátottak szellemi és fizikai teherbíró képességét. A foglalkozások mellett a pihenésre is hagyunk elég időt. Az öregedés során fokozódik az ember pihenés iránti szükséglete, a fizikai fáradtságot is lassabban piheni ki az öregedő szervezet, mint a fiatal. 
Változatosság: Időnként más-más foglalkozást kell kitalálni és felkínálni a gondozottaknak. Váltakozva szervezünk egyéni és csoportos foglakozásokat, aktív és passzív részvételt, illetve fizikai és szellemi tevékenységet igénylőt. Ha sokáig ugyanazt a tevékenységet kell végezni, akkor az unalmassá válik a klubtagok számára.

Legyen mindenkinek feladata: A feladat legyen alkalmas az egyén érdeklődésének felkeltésére. Feleljen meg a gondozott személyiségének, életkorának, értelmi és fizikai állapotának, ne legyen számára megterhelő. Fontos, hogy érezze „Szükség van rám...”

Értékelés, elismerés: A legjelentősebb érték a sikerélmény, és ez általában a legfőbb motiváló tényező is. A gondozott igyekezetét, akaratát kell figyelembe venni. Nem feltétlenül szükséges a tevékenység esztétikai színvonalát értékelni, hanem a szabadidő értelmes, hasznos eltöltését kell jutalmazni, dicsérni.

Rendkívül fontos a foglalkoztatási programoknál a segítő és gátló tényezők figyelemmel kísérése. A segítő tényezőkhöz tartozik a foglakoztatásban résztvevők pozitív személyisége, hozzáállása — ezek a személyi feltételek.

Az akadályozó tényezők közé tartozik a csökkent vagy hiányzó motiváció a klubtagok részéről, a labilis hangulat, a különböző érzékszervi károsodások, a fizikai állapot, az aktuálisan jelentkező szomatikus tünetek, de akadályozó tényező lehet a gondozó negatív szemlélete a foglalkozásokkal kapcsolatban. Az ellátottak tiltakozásának, ellenállásának több oka is lehet: pl. a félelem, hogy nem tudja megtenni, amit kérnek tőle; félhet a számára ismeretlen, új tevékenységtől, félhet, hogy a társai vagy a gondozók kinevetik, kigúnyolják.

Minden klubban vannak olyan ellátottak is, akik egészségi állapotuk vagy egyéb más ok miatt nem tudnak, vagy nem vehetnek részt egy-egy programon. Az ö esetükben azt igyekszünk elérni, hogy a passzív foglakoztatásuk biztosított legyen, azaz csendes szemlélőként vegyenek részt a foglalkoztatásban, legyenek részesei a közösségnek.

A klubtagoknak tehát különféle lehetőségeket biztosítunk az idő hasznos eltöltésére a klubon kívül és belül egyaránt.

\section{Programok az idősek klubjain falain belül és kívül}

Tagjai vagyunk a Sz.-Sz.-B. Megyei Nyugdíjasok Érdekvédelmi Szövetségének, és a Nyíregyháza és Térsége Nyugdíjas Szövetségnek is. Mindkét szövetségen keresztül segítséget nyújtunk az időseinknek abban, hogy az érdekképviseletük ellátása megfelelő legyen, a hagyományokat ápolni tudják, az élethosszig tartó tanulás folyamatában aktívan részt 
vehessenek. Ennek jegyében részt vesznek klubtagjaink az általuk szervezett rendezvényeken, „Ki mit tudokon?”, a kulturális vetélkedőkön és az általunk szervezett Idősek Akadémiája rendezvény sorozaton. A generációk együttmüködése kapcsán rendszeres és folyamatos kapcsolatot építettünk ki, és tartunk fent a bölcsődékkel, óvodákkal, iskolákkal. A rendszeres orvosi ellátás a háziorvosi szolgálatok által biztosított.

Az idősek ellátása során az intézményünk fontosnak tartja a holisztikus szemlélet gyakorlati megvalósulását. Ahhoz, hogy az idősek jól érezzék magukat megfelelő segítő környezet szükséges. Alapvető céljaink között szerepel az idősek testi-szellemi frissességének, lelki egyensúlyának megőrzése, helyreállítása, az egészséges öregedés és az élethosszig tartó tanulás elvének gyakorlati megvalósítása, szociális helyzetük javítása, társadalmi és családi kapcsolataik fenntartása. Az idősek körében gyakrabban előforduló testifizikai elváltozások lelki sérülésekkel is járhatnak, a lelki sérülések a testi müködésekre hatva pszichoszomatikus elváltozásokat okozhatnak. A mentálhigiénés munkatárs egyéni és csoportfoglalkozásokat tart az ellátottak részére, amelyek célja az idősek aktivitásának megőrzése, fejlesztése, pszichés állapotuk szinten tartása, javítása.

Szociális helyzetük változása, romlása hatással van a testi és lelki folyamatokra. Nagyon fontosnak tartjuk a foglalkoztatást, a megfelelő programok biztosítását, szervezését, amivel elkerülhető illetve megszüntethető a tétlenség, a feleslegessé válás érzése, az izoláció. Az évek során bizonyítást nyert, hogy anyagi ráfordítás nélkül, illetve kevés pénzügyi befektetéssel is tudunk olyan programokat szervezni, amelyek hasznosak minden résztvevő számára és bárhol megvalósíthatóak.

Az intézmény széles kapcsolatrendszere is lehetővé teszi, hogy az idősek érdekében a különböző területeken dolgozó szakemberek együtt tudjanak működni, mint pl.: orvosok, egészségügyi szakemberek, pedagógusok, népmüvelők, lelkészek, segélyszervezetek munkatársai.

A klubtagok számára folyamatosan biztosított a lehetőség a különböző programokon való részvételre. A klubtagok rendszeresen részt vesznek a Móricz Zsigmond Színház délelötti nyilvános föpróbáin, a helyi önkormányzat által szervezett programokon (Hello Nyíregyháza, Civil Városnap, KI-MIT-TUD, nemzeti ünnepek alkalmából szervezett megemlékezések, ünnepi müsorok), a megyei és városi nyugdíjas szövetség által szervezett programok (megyei sportverseny, Madarak-fák napja, vers- és prózamondó versenyek). 
Idén több alkalommal kerültek megszervezésre kirándulások is a klubtagok számára (pl.: Vizsoly, Máriapócs, Harangod, Budapest) valamint közösségi találkozók (pl.: Ezüst Juniális, Szüreti mulatság, Márton-nap).

1994-től kezdődően évente két alkalommal, ősszel és tavasszal Idősek Akadémiáját szervezünk. Az Akadémia keretében különböző: - természetgyógyászati, orvosi, jogi, pszichológiai, vallási, történelmi- témájú előadásokat hallhatnak a résztvevők. Az előadások után lehetőség van kérdések feltevésére az előadókhoz és négyszemközti beszélgetésekre is, de az elsődleges cél az élethosszig tartó tanuláson túl a kapcsolatok erősítése, új barátságok kialakulásának létrejötte. Ebben az évben is két alkalommal került megrendezésre az Idősek Akadémiája a Római Katolikus Plébánián, mely igen népszerü volt a város időskorú lakossága körében. Valamennyi előadás teltházas közönség előtt zajlott.

A 3.sz. Idősek Klubjában minden hónap első hétfőjén evangélikus istentiszteletet, háromhetente keddi napokon református istentiszteletet tartanak.

A ,generációk együttmüködése” programunk azt a célt is szolgálja, hogy az intézményben közösségi szolgálatot töltő fiatalok megismerkedjenek az időskorral járó elváltozásokkal, toleránsabbak, empatikusabbak legyenek az idősekkel, elősegítsük az idősek integrációját és így hozzájáruljunk az idősekhez kapcsolódó társadalmi attitüd megváltoztatásához. 2014-től kezdődően 39 középiskolás diák töltötte az intézményben a közösségi szolgálatát.

\section{Az idősek nappali ellátását igénybevevők létszámának alakulása az elmúlt időszakban}

2015 decemberében 190 fövel volt megállapodásunk nappali ellátás igénybevételére. 2016. évben 47 fővel kötöttünk megállapodást és 32 fő kérte az ellátás megszüntetését.

A nappali ellátás igénybevételének alakulása a látogatások száma alapján:

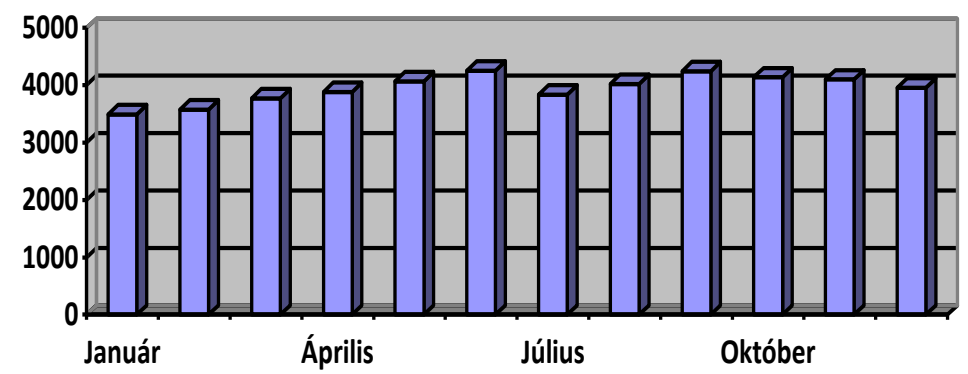

पlátogatás szám

A nappali ellátás kihasználtságának alakulása százalékos értékben: 


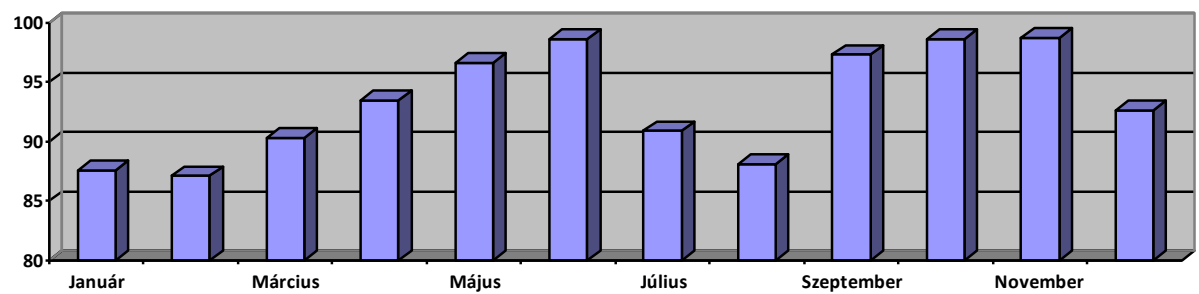

A diagramból is kitünik, hogy a nappali ellátás kihasználtsága az év folyamán folyamatosan nőtt, a július és augusztusi hónapban a nyaralások miatt, valamint a Nyírszőlősi Idősek klubja felújítási munkálatai miatt elrendelt zárva tartás miatt a kihasználtság csökkent, illetve decemberben a karácsonyi ünnepek idején többen utaznak el a gyermekeikhez, unokáikhoz.

Az elmúlt időszakban a következőképpen alakult az idősek klubjaiban a létszám:

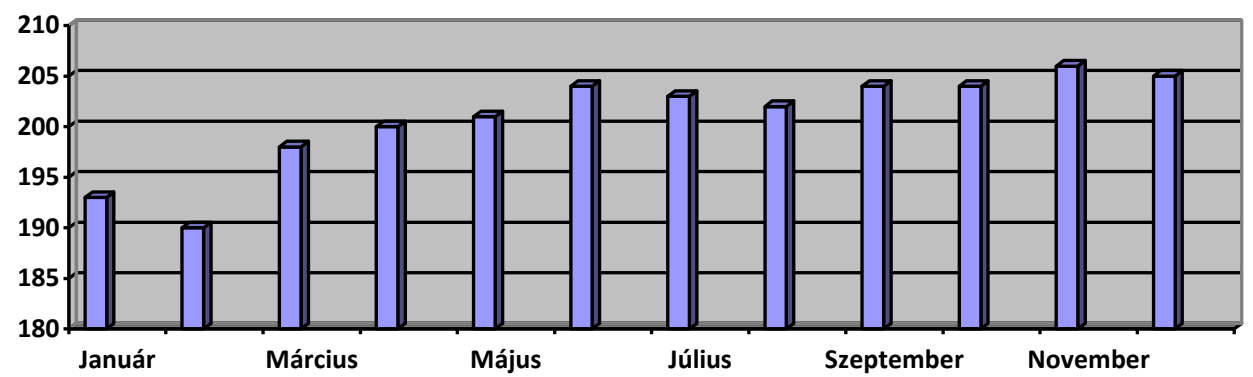

A klubtagok száma az elmúlt időszakban folyamatosan nőtt. A klubokban az engedélyezett féröhelyek száma 181, idén decemberben jelenleg 205 fővel van megállapodásunk idősek nappali ellátása igénybevételére. A klubtagjaink $72 \%$-a nő, $28 \%$-a férfi.

Az idősek klubjában a klubtagok kor szerinti összetétele:
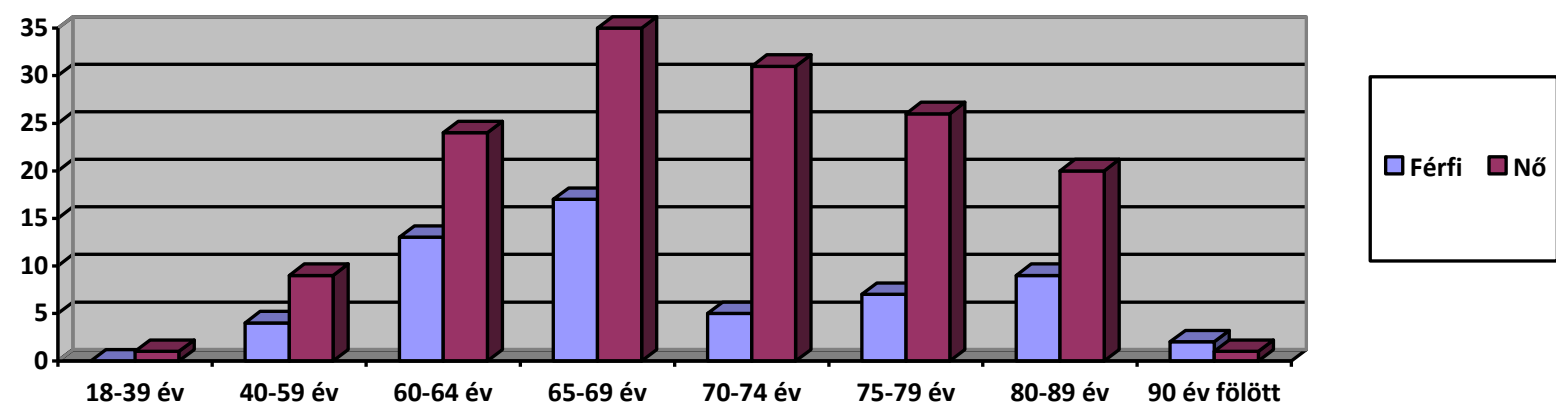

A klubtagok többsége a 70 éven felüli korcsoportba tartozik. Önellátásra részben képesek. Jellemzően egyedül élnek. A nemek arányát tekintve a női klubtagok vannak többségben. A 70 éven felülieknek speciálisabb gondozási szükséglete van, mint a fiatalabb korosztály tagjainak. Nagyobb odafigyelést, több törődést igényelnek munkatársaktól. 


\section{A klubtagok}

$\Rightarrow 2 \%$ látássérült,

$\Rightarrow 12 \%$ mozgássérült,

$\Rightarrow 17 \%$ hallássérült,

$\Rightarrow 14 \%$-uk valamilyen pszichiátriai kórképpel rendelkezik,

$\Rightarrow 2 \%$-uk halmozottan sérült.

\section{Összegzés}

Mindezekből egyértelmüen kiderül, hogy milyen nagy jelentősége van az idősgondozás eme formájának. A hozzátartozók biztonságban tudhatják napközben idős szüleiket. A rendszeres foglalkoztatás, a programok és az élethosszig tartó tanulás eredményeként javul az ellátottak szellemi frissessége, lelki egyensúlyuk is helyreáll. Mindezek által kevesebb terhet rónak az egészségügyi ellátórendszerre és az egészséges öregedés normáinak megfelelően élik mindennapjaikat.

\section{Szerzö:}

Dancsné Barna Hilda

okleveles egészségügyi szociális munkás

szakmai egységvezető

Nyíregyházi Szociális Gondozási Központ 